\title{
Toast na cześć... \\ Reakcje społeczne na śmierć Józefa Stalina i kampania propagandowa wokół uroczystości żałobnych w województwie bydgoskim w marcu $1953 \mathrm{r}$.
}

\section{Wstęp}

W bloku państw sowieckich śmierć Józefa Stalina, „głównego architekta terroru”, , spowodowała w perspektywie nadchodzących lat proces niezmiernie istotnych zmian społeczno-politycznych ${ }^{2}$. Polityczna odwilż następowała jednak powoli ${ }^{3}$. Wbrew nadziejom Polaków ${ }^{4}$, w tym mieszkańców województwa bydgoskiego, proces demokratyzacji i liberalizacji życia nie rozpoczął się wraz ze zgonem jednego z największych zbrodniarzy w historii ludzkości ${ }^{5}$. Po okresie trwającej kilkanaście dni żałoby i zakończeniu celebry związanej z pierwszomajowym świętem represje wobec społeczeństwa polskiego się nasiliły ${ }^{6}$. Było to szczególnie widoczne od drugiej połowy 1953 r. w polityce wobec wsi, a wyrażało się wzrostem liczby aresztowanych rolników

${ }^{1}$ Określenie użyto za: E. Mawdsley, Czas Stalina, Warszawa 2012, s. 148.

${ }^{2}$ R. Kozłowski, Październik '56 w regionie kujawsko-pomorskim w świetle niepublikowanych źródet PZPR, Włocławek 2004, s. 12; P. Machcewicz, Polski rok 1956, Warszawa 1993, s.12.

${ }^{3}$ Warto wspomnieć, na co zwrócił uwagę prof. Mirosław Golon, że w wypadku większości krajów Europy Środkowo-Wschodniej rok 1953 nie zaowocował nawet zmianą osoby na stanowisku sowieckiego ambasadora. Co prawda należy podkreślić fakt, iż w Polsce w lipcu 1953 r., czyli w okresie ważnych przetasowań na Kremlu, ówcześnie urzędującego ambasadora Arkadija Aleksandrowicza Sobolewa zastąpił Gierorgij Popow. Na podstawie: M. Golon, Ambasadorowie Stalina - radzieccy dyplomaci w Europie Środkowo-Wschodniej i na Bałkanach w latach 1944-1953, „Czasy Nowożytne” 2005, t. XVIII-XIX, s. 131, 162.

${ }^{4} \mathrm{Na}$ temat reakcji i krótkotrwałej „euforii” w środowiskach i kołach emigracyjnych zob. P. Wójtowicz, Obraz Związku Sowieckiego w ujęciu polskiej emigracji politycznej w Wielkiej Brytanii, Warszawa 2008, s. 76.

${ }^{5} \mathrm{Na}$ temat zbrodni w okresie rządów Józefa Stalina zob. np. S. Courtois, N. Werth, J. L Panné, A. Paczkowski, K. Bartošek, J. L. Margolin, Czarna księga komunizmu. Zbrodnie, terror, prześladowania, Warszawa 1999 (cz. 1: Państwo przeciw społeczeństwu. Przemoc, represje i terror w Zwiąku Sowieckim).

${ }^{6}$ Zob. P. Machcewicz, Polski rok 1956, s. 13, 14. 
niemogących się wywiązać z obowiązkowych dostaw zboża ${ }^{7}$. Powolna destalinizacja systemu rozpoczęła się w regionie, podobnie jak w całym kraju, znacznie później niż w pozostałych krajach satelickich sowieckiego imperium, około połowy 1954 r. $^{8}$ Przez najbliższe trzy lata, tak jak i za życia tyrana, w państwach bloku sowieckiego trwał kult osoby Stalina, nadal też stawiano mu pomniki i nazywano jego imieniem fabryki i ulice ${ }^{9}$. Jednak pierwsze symptomy zmiany i odwilży, takie jak potępienie „,beriowszczyzny”, a wkrótce reorganizacja i krytyka aparatu bezpieczeństwa czy amnestia ${ }^{10}$, odbijały się głośnym echem w regionie, budząc nadzieję na polityczną ewolucję systemu oraz poprawę ciężkich warunków codziennej egzystencji, zarówno w wymiarze fizycznym, jak i psychicznym. Jak bowiem pisał T. Synder — stalinizm był nie tylko systemem politycznym, ale i moralnym, a „niewinność oraz wina służyły w nim za kategorie prawne, a zarazem psychologiczne"

Światło na oficjalnie rejestrowane reakcje oraz nastroje w związku z agonią i śmiercią Stalina w dużym stopniu rzucają meldunki dzienne Wydziału Organizacyjnego KW PZPR w Bydgoszczy do KC PZPR w Warszawie ${ }^{12}$. Pierwsze informacje pojawiają się w trzecim dziennym meldunku wysłanym 5 marca. Jak wynika z dokumentacji, temat śmierci Stalina był stale obecny w meldunkach terenu do Warszawy na pewno do 10 marca (kolejny meldunek, datowany jest dopiero na 14 marca, należy jednak podkreślić, mimo trzydniowej przerwy w dokumentacji, zachowaną ciągłość w jej numeracji). Po tej dacie meldunki o nastrojach społeczności regionu w kontekście zgonu genseka ustały, ustępując miejsca innym ważkim dla regionu tematom (np. wiosennej akcji siewnej). Natomiast, co oczywiste, nadal informowano KC o większych incydentach o charakterze antysowieckim i antystalinowskim (przeciwstawianiu się dobrej pamięci o zbrodniarzu). Można zatem przyjąć, iż największe natężenie komentarzy na temat śmierci Stalina przypada w regionie pomiędzy 5 a 14 marca. Zainteresowanie sprawą śmierci Stalina uwidoczniało się doskonale w zapotrzebowaniu na prasę codzienną i skutkowało natychmiastowym wykupem całego dostępnego nakładu. Dla przykładu 6 marca z chwilą ukazania się opóźnionego nakładu organu partyjnej instancji wojewódzkiej „Gazety Pomorskiej” w Bydgoszczy dosłownie w ciągu kilku minut wykupiono ponad tysiąc egzemplarzy tego tytułu, rozprowadzanych przez kioski RSW Prasa. Natomiast w sąsiednim Grudziądzu natychmiast rozprowadzono trzysta egzemplarzy gazet dostarczonych do jednego z tamtejszych zakładów ${ }^{13}$. Odnotowywano wówczas równocześnie masowe gromadzenie się ludności na specjalnych zebraniach, masówkach, przy publicznych głośnikach radiowych, a także w pobliżu redakcji wspomnianej już „Gazety Pomorskiej”. Było to szczególnie widoczne 6 marca, kiedy organ KW PZPR wyszedł dopiero w godzinach popołudniowych ${ }^{14}$.

Jak podsumował Robert Kupiecki w pracy poświęconej kultowi Stalina w Polsce, pierwszy dzień po śmierci upłynął w kraju ,pod znakiem wstrząsu” "15. Jednak, podobnie jak w przypadku innych akcji propagandowych, żałobę bardzo szybko „uporządkowano”; moż-

\footnotetext{
${ }^{7}$ Zob. IPN BU 01265/36/J, Sprawozdania Szefa WUBP w Bydgoszczy (sierpień, wrzesień, październik, listopad i grudzień 1953 r., k. 77-157.

${ }^{8}$ P. Machcewicz, Polski rok 1956, k. 14.

9 Za: J. Eisler, Siedmiu wspaniatych. Poczet pierwszych sekretarzy KC PZPR, Warszawa 2014, k. 86 (Bolesław Bierut).

${ }^{10}$ W kwietniu $1956 \mathrm{r}$.

${ }^{11}$ T. Snyder, Skrwawione ziemie. Europa między Hitlerem a Stalinem, Warszawa 2011, s. 432.

12 Zobacz: APB 1935/1586, Meldunki Referatu Sprawozdawczego KW PZPR w Bydgoszczy do Wydziału Organizacyjnego Referatu Sprawozdawczego KC PZPR w Warszawie (1953).

${ }^{13}$ Ibidem, Meldunek nr 56/53, 7 III 1953 r., k. 148.

14 Ibidem.

${ }^{15}$ R. Kupiecki, Natchnienie milionów. Kult Stalina 1944-1956, Warszawa 1993, s. 158.
} 
na powiedzieć, że wręcz zuniformizowano bardzo szczegółowymi wytycznymi z KC, regulującymi właściwie wszelkie sprawy związane z uroczystościami i kultem ku czci zmarłego ${ }^{16}$. Warto też podkreślić, iż władze, nie mogąc sobie pozwolić na jakąkolwiek w tej kwestii „spontaniczność" ${ }^{17}$, nie zdołały w krótkim czasie, jaki upłynął od śmierci do pogrzebu, przygotować jakiejś bardziej ,wysublimowanej oprawy artystycznej” uroczystości żałobnych ${ }^{18}$.

\section{Agonia po sowiecku, czyli ,poważny stan zdrowia”}

W związku z oficjalnymi komunikatami o chorobie Stalina (zwaną eufemistycznie ,poważnym stanem zdrowia", podczas gdy de facto była to trwająca dłuższy czas agonia ${ }^{19}$ ), w całym regionie śledzono z narastającym lawinowo zainteresowaniem wszelkie poświęcone jej informacje: „Społeczeństwo naszego województwa przyjęło tę wiadomość z wielkim smutkiem i z wielkim zainteresowaniem śledzi komunikaty radiowe o stanie zdrowia tow. Stalina" ${ }^{20}$ — raportowali do Warszawy pracownicy referatu sprawozdawczego komitetu wojewódzkiego w Bydgoszczy.

Pierwsze informacje o złym stanie zdrowia Stalina zaczęły pojawiać się w przestrzeni publicznej regionu w masowej formie na pewno już w 4 marca. Tego dnia na toruńskim Uniwersytecie Mikołaja Kopernika już w godzinach rannych „komentowano tę sprawę” oraz obserwowano „wielkie zaniepokojenie wśród studentów”21. Tego dnia również „Gazeta Pomorska” poinformowała czytelników, iż „Naród Polski z bólem przyjął wiadomość o chorobie Józefa Stalina”22.

W okresie bezpośrednio poprzedzającym śmierć sowieckiego dyktatora pracownicy zakładów pracy i instytucji z całego regionu zbiorowo wysłuchiwali komunikatów radiowych, organizując częstokroć w tym celu okolicznościowe masówki, podczas których załogi i organizacje partyjne podejmowały się wykonania np. dodatkowej produkcji. Dla przykładu organizacja partyjna przy Hucie Szkła nr 12 w Turze zorganizowała specjalną masówkę w celu wysłuchania komunikatu radiowego o stanie zdrowia Stalina, a załoga postanowiła „,iść po linii wskazań tow. Stalina i wzmóc swój wysiłek na odcinku produkcji” oraz wykonać ponadplanowe zadania na kwotę 145 tys. $\mathrm{zl}^{23}$. Na podbydgoskiej wsi jedną z najczęstszych form oddawania czci umierającemu było spontaniczne organizowanie spółdzielni produkcyjnych, przekraczanie planu i deklarowanie zwiększenia wydajności z hektara, a także przedterminowe oddanie obowiązkowych dostaw i ukończenie siewów. Na wieść o chorobie Stalina chłopi z gromady Grzeczna Panna zorganizowali spółdzielnie produkcyjną, a rolnicy z Buszkowa w powiecie szubińskim podczas zebrania założycielskiego spółdzielni produkcyjnej ,,w dyskusji nawiązywali do poważnego stanu sowieckiego dyktatora, wskazując, iż ,mają obecnie możność budować lepszą przyszłość, co zawdzięczają tow. Stalinowi”24.

\footnotetext{
${ }^{16}$ Ibidem.

${ }^{17}$ Ibidem.

${ }_{18}$ Ibidem, k. 170.

${ }^{19}$ Zob. na ten temat doskonałą książkę S. S. Montefiore, Stalin. Dwór czerwonego cara, Warszawa 2010, w której bardzo szczegółowo opisano ostatnie chwile życia (agonii) Stalina.

${ }^{20}$ APB 1935/1586, Meldunek Referatu Sprawozdawczego KW PZPR w Bydgoszczy do WO Ref. Spraw. KC PZPR w Warszawie, Bydgoszcz, 5 III 1953 r., k. 154.

${ }^{21}$ Ibidem.

22 „Gazeta Pomorska” 1953, nr 55, s. 1.

${ }^{23}$ APB 1935/1586, Meldunek Referatu Sprawozdawczego KW PZPR w Bydgoszczy do WO Ref. Spraw. KC PZPR w Warszawie, Bydgoszcz, 5 III 1953 r., k. 154.

${ }^{24}$ Ibidem.
} 


\section{„Miłość setek milionów ludzi pracy”. Akcje propagandowe, wiece, masówki, czyny i zobowiązania po śmierci Stalina}

Akcje propagandowe związane z kultem Stalina i umacnianiem jedności komunistycznej partii (masówki, zebrania, czyny i rezolucje) oczywiście przybrały na sile w regionie od 6 marca, natychmiast po ukazaniu się oficjalnych informacji o śmierci Stalina. W wielu zakładach przeprowadzano standardowo krótkie masówki, wysłuchując przy tym audycji radiowych (Zakłady Mięsne w Czerniejewicach w pow. włocławskim) oraz wystosowując zwyczajowe telegramy kondolencyjne (np. do ambasadora ZSRS A. Sobolewa), a także podejmując zobowiązania produkcyjne ${ }^{25}$. Dzieci i młodzież we wszystkich zradiofonizowanych szkołach regionu zostały zmuszone do odsłuchania komunikatu radiowego, dodatkowo jedną lekcję szkolną poświęcono specjalnej pogadance o Stalinie. W Zasadniczej Szkole Metalowo-Budowlanej w Grudziądzu aktyw na żałobnej masówce wystosował list do tamtejszego komitetu miejskiego z prośbą o przekazanie wyrazów współczucia i żalu (z meldunku wykreślono słowo „nieutulonego”), z jakim młodzież przyjęła wiadomość o ,śmierci ukochanego Ojca Młodzieży całego świata" ${ }^{, 26}$. Warto podkreślić, że swoistym centrum partyjnego mikroświata w terenie po śmierci Józefa Stalina stawały się siedziby komitetów powiatowych i miejskich, dokąd od samego rana 6 marca udawał się tłumnie głównie nieetatowy aktyw partyjny, robotnicy i chłopi ${ }^{27}$, zarówno w celu uzyskania informacji i wytycznych, jak i po to, aby wyrazić żal i smutek, a także z powodu strachu i dezorientacji w obliczu kryzysowej, niemającej precedensu sytuacji. Chłopi z powiatu szubińskiego na masówce w gminie Sipiury dla uczczenia pamięci zmarłego Stalina podpisali deklaracje akcesu do spółdzielni i ponadto zorganizowali komitet założycielski ${ }^{28}$.

W związku ze śmiercią Stalina Prezydium WRN w Bydgoszczy za pośrednictwem „Gazety Pomorskiej” wezwało ludność całego regionu do dekorowania wszystkich budynków (publicznych i mieszkalnych), ,portretami Towarzysza Józefa Stalina przybranymi czerwienią i krepą oraz do wywieszania flag narodowych i czerwonych opuszczonych do połowy masztu, względnie pochylnych i spowitych krepą"29. Zdaniem KW PZPR już 6 marca nastąpiło „nasilone” dekorowanie przestrzeni publicznej i prywatnej w miastach i powiatach flagami i portretami Stalina, częstokroć przybranymi kirem. Ponadto aktyw gminny i gromadzki został pouczony o wytycznych KC w sprawie wykorzystania odbywających się zebrań gromadzkich do uczczenia pamięci Stalina ${ }^{30}$. Jak raportowano do Warszawy, na terenie dwóch miast, gdzie ,wrogi wpływ wywierał miejscowy kler”, akcja ta nie przebiegała prawidłowo (w Bydgoszczy oraz Toruniu). Kontrola wykazała, że nie tylko nie była tam „nasilona”, ale wręcz w wielu wypadkach przebiegała ,niedbale”, a poważnym mankamentem wielu dekoracji było ich „odpolitycznienie”, jak eufemistycznie nazwano brak w ikonosferze regionu haseł zaleconych przez $\mathrm{KC}^{31}$. Wobec zaistniałej sytuacji i dla sprawdzenia dekoracji powstających spontanicznie (,oddających wyraz chwili”) w całym województwie bydgoskim powołano tzw. trójki kontrolne złożone z członków KFN i ZMP ${ }^{32}$.

\footnotetext{
${ }^{25}$ Ibidem, Meldunek nr 54/53, 6 III 1953 r., k. 152.

${ }^{26}$ Ibidem; w oryginale UKOCHANEGO OJCA MŁODZIEŻY pisane majuskułą.

${ }^{27}$ APB 1935/1586, Meldunek nr 54/53, 6 III 1953 r., k. 152.

${ }^{28}$ Ibidem, Meldunek nr 58/53, 7 III 1953 r., k. 144.

${ }^{29}$ Wezwanie Prezydium WRN do ludności województwa bydgoskiego, „Gazeta Pomorska” 1953, nr 56, s. 4.

${ }^{30}$ APB 1935/1586, Meldunek nr 54/53, 6 III 1953 r., k. 152.

${ }^{31}$ Ibidem, Meldunek nr 57/53, Bydgoszcz 7 III 1953 r., k. 146.

${ }^{32}$ Ibidem.
} 
Pamięć Stalina czczono na dziesiątkach akademii, masówek i wieczernic, w wielu zakładach pracy i instytucjach całego regionu, a odczytywane tam referaty i mowy były zazwyczaj oparte na materiałach przygotowanych przez KC PZPR, dlatego można przypuszczać, że w większości miejsc miały zbliżony charakter i bliźniaczy przebieg ${ }^{33}$. Warto podkreślić, iż masówki z 6 marca cechowała znacznie lepsza frekwencja niż inne dotąd organizowane przez partię zebrania. Tylko w Zakładach Naprawczych Taboru Kolejowego w Bydgoszczy na żałobny wiec stawiło się 4 tys. pracowników, w tym spora część osób w tym dniu urlopowanych; w Państwowym Zakładzie Budownictwa Mieszkaniowego pojawiły się dwie pełne zmiany. W Inowrocławiu na dwudziestu trzech masówkach odbytych tego dnia stawiło się łącznie 3 tys. osób i jak odnotowano, panował na nich nastrój powagi i smutku (szczególnie podczas momentu odczytywania tekstów oficjalnych, kiedy na twarzach zebranych ,uwidaczniał się głęboki żal i smutek") $)^{34}$.

Zgodnie $\mathrm{z}$ dyspozycją KC najwięcej masówek odbywało się w regionie bezpośrednio po śmierci genseka, to jest 6-7 marca. W całym województwie tylko w ciągu tych dwóch dni przeprowadzono masówki w 1746 miejscach, w tym w 504 zakładach produkcyjnych, 416 instytucjach i urzędach, 267 szkołach, 117 PGR, 95 spółdzielniach i 347 gromadach indywidualnych. Łącznie wzięło w nich udział przeszło 146 tys. mieszkańców regionu, z czego najwięcej w zakładach pracy - 67 tys., szkołach - 38,6 tys., i w gromadach - 14 tys. ${ }^{35}$ O powadze, $\mathrm{z}$ jaką traktowano owe masówki, świadczyła nie tylko bardzo dobra frekwencja (,niespotykana dotąd w żadnych innych akcjach”), ale również fakt, że komunikatów wysłuchiwano „na stojącą i w skupieniu”, nie wychodząc w tym czasie i „wstrzymując się od palenia papierosów”, a także miały miejsce „częste wypadki płaczu kobiet”36.

Celem masówek było nie tylko uczczenie pamięci Stalina, ale - co równie ważne zapoznanie społeczeństwa z biuletynem KC KPZR i Prezydium Rady Najwyższej ZSRS do narodu radzieckiego oraz biuletynem KC PZPR i Rady Ministrów do narodu polskiego. Służyć to miało konsolidacji społeczeństwa wokół ideologii komunistycznej partii, ale także ukróceniu plotek i spekulacji o rzekomych powodach śmierci i przebiegu choroby Stalina. Tu ogromne zasługi oddawała reżimowa prasa, zwłaszcza organy partyjne. Dla przykładu w specjalnym czarno-białym, żałobnym wydaniu „Gazety Pomorskiej” całą szpaltę poświęcono na artykuł Józef Stalin nie żyje opatrzony wizerunkiem zmarłego dyktatora ${ }^{37}$, pod którym opublikowano list KC KPZR, Rady Ministrów i Rady Najwyższej ZSRS do wszystkich członków partii i wszystkich ludzi pracy Związku Sowieckiego ${ }^{38}$. Ponadto na kolejnych stronach zamieszczono listy najwyższych władz PRL do polskiego społeczeństwa oraz do władz sowieckich $^{39}$, a także artykuł wstępny z sowieckiej „Prawdy”. ${ }^{40}$. Dalej znalazły się także komunikaty władz sowieckich na temat uroczystości pogrzebowych, jak również orzeczenie lekarskie o przebiegu choroby i śmierci Stalina, łącznie z dwoma biuletynami o stanie jego zdrowia z 5 marca (z godz. drugiej i szesnastej). Ponadto dwa przydługie peany, jeden autor-

\footnotetext{
${ }^{33}$ R. Kozłowski, Październik' 56 r. w regionie, s. 16.

${ }^{34}$ APB 1935/1586, Meldunek nr 55/53, Bydgoszcz 6 III 1953 r., k. 151.

${ }^{35}$ Ibidem, Meldunek nr 58/53, Bydgoszcz 6 III 1953 r., k. 143.

${ }^{36}$ Ibidem.

${ }^{37}$ Porównaj: APB 1935/2266, Śmierć Józefa Wissarionowicza Stalina; Przestało bić serce wodza ludzkości - Wielkiego Stalina, „Trybuna Ludu” 1953, nr 66 (1492).

${ }^{38}$ Józef Stalin nie żyje, „Gazeta Pomorska” 1953, nr 56, s. 1.

${ }^{39}$ List KC PZPR Rady Państwa i Rady Ministrów PRL do Robotników, chtopów i inteligencji pracującej! Do kobiet polskich i młodzieży! Do żotnierzy polskich! Do narodu Polskiego; List do KC KPZR, Rady Ministrów i Prezydium Rady Najwyższej ZSRR, ibidem, 1953, nr 56 (1434), s. 2.

${ }^{40}$ Wielka jedność partii i narodu. Artykut wstęny „Prawdy”, ibidem, s. 2, 3.
} 
stwa Michała Isakowskiego Pieśń o Stalinie w przekładzie Gabriela Karskiego oraz fragmenty poematu Władysława Broniewskiego Słowo o Stalinie ${ }^{41}$.

Równolegle do masówek odbywających się pod auspicjami zakładów pracy, szkół czy spółdzielni produkcyjnych organizowano wielkie ogólnomiejskie wiece, których celem było „uczczenie pamięci towarzysza Stalina”, ale i wyrażenie poparcia dla linii partii i demonstracja partyjnej jedności. Tylko jednego dnia — 8 marca — pod auspicjami KW PZPR w Bydgoszczy i komitetów miejskich zorganizowano trzy wielkie spędy ludności w Bydgoszczy, Włocławku i Grudziądzu, w których wzięło udział około 18 tys. osób, w tym najwięcej wcale nie w stolicy województwa Bydgoszczy (7 tys.), ale we Włocławku (10 tys.); najmniej zaś w Grudziądzu (ok. 1,5 tys.). Jak obliczono, około 30 proc. zebranych stanowili ludzie młodzi, a około 50 proc. kobiety ${ }^{42}$. Na masówkach tych panował nastrój powagi, spokój i dyscyplina, zarówno podczas przejścia do hal, gdzie odbywały się zebrania, jak i w trakcie samego spotkania. Działo się tak mimo faktu, że wiele osób w Bydgoszczy i Włocławku wystawało pod budynkami, gdzie odbywały się uroczystości, nie mogąc już wejść do zapełnionego do maksimum wnętrza. Na zgromadzeniach przemawiali dostojnicy partyjni, sekretarze komitetów partyjnych, przedstawiciele ZSL, ZMP oraz inteligencji, a w Bydgoszczy, co oczywiste, głos zabrał sam I sekretarz KW PZPR Władysław Kruczek ${ }^{43}$.

$\mathrm{Na}$ terenach wiejskich odnotowano niespotykane dotąd zjawisko obecności kobiet z dziećmi oraz osób starszych na masówkach organizowanych w gromadach, spółdzielniach produkcyjnych i PGR-ach ${ }^{44}$. Jak podkreślano, na tych zebraniach wiele starszych osób „dokumentowało głębokie uznanie dla zasług tow. Stalina”. Zabierano głos, czy też wygłaszano mowy pochwalne na cześć zmarłego, w tonie zbliżonym do wystąpienia siedemdziesięciodwuletniej kobiety z gminy Ślesin: „Ja teraz wychowuję tylko maleńkie dzieci, gdybym umarła to nie przyniosłoby wielkiej szkody gromadzie, a nieśmiertelna mądrość Stalina potrzebna była przez długie lata dla wszystkich ludzi świata i musiał umrzeć" ${ }^{45}$.

Wysoka, niespotykana dotąd frekwencja na zebraniach gromadzkich cieszyła partyjnych decydentów głównie z powodu podejmowania na nich spontanicznych decyzji o zakładaniu nowych spółdzielni produkcyjnych, co rolnicy traktowali jako wyraz czci dla zmarłego ${ }^{46}$. Jak podkreślono w jednym z meldunków partyjnych, ,jest już szereg osiągnięć w województwie na tym odcinku" ${ }^{47}$. Rzeczywiście, porównując liczbę spółdzielni powstałych w województwie bydgoskim w marcu 1953 r. (62) do liczby spółdzielni założonych w styczniu (17) czy też kwietniu (15), można zauważyć prawie czterokrotny ich wzrost. Warto jednak podkreślić, iż w lutym 1953 r. zostało ich utworzonych w tym regionie aż 107, zatem w sumie więcej niż w styczniu, marcu i kwietniu razem. (Ogółem pod koniec kwietnia 1953 r. liczba spółdzielni produkcyjnych w województwie bydgoskim wynosiła łącznie 549) ${ }^{48}$.

W wielu wiejskich miejscowościach całego regionu żałoba po śmierci Stalina sprzyjała podejmowaniu spontanicznych zobowiązań, takich jak oddawanie dodatkowych bekonów, dodatkowa kontraktacja buraka cukrowego, podnoszenie pogłowia stanu zwierząt hodowlanych czy też skracanie akcji siewnej. W gromadach zaczęto również odnotowywać fakty

\footnotetext{
${ }^{41}$ Zob. M. Isakowski, Pieśń o Stalinie; W. Broniewski, Stowo o Stalinie, ibidem.

${ }^{42}$ APB 1935/1586, Meldunek nr 60/53, 9 III 1953 r., k. 134.

${ }^{43}$ Ibidem.

${ }^{44}$ W dokumencie określonych jako „starcy”. Zob. APB 1935/1586, Meldunek nr 58/53, Bydgoszcz

6 III 1953 r., k. 143; ibidem, Meldunek nr 59/53, 8 III 1953 r., k. 139.

${ }^{45}$ APB 1935/1586, Meldunek nr 59/53, 8 III 1953 r., k. 139.

${ }^{46}$ Zob. np.: Ibidem, k. 140.

${ }^{47}$ Ibidem; APB 1935/1586, Meldunek nr 60/53, 9 III 1953 r., k. 137.

${ }^{48}$ Ibidem, Meldunek nr 86/53, 28 IV 1953 r., k. 164.
} 
wstępowania do partii bezpartyjnych dotąd chłopów. Dla przykładu pomiędzy 7 a 8 marca w powiecie lipnowskim zgłosiło się do PZPR siedmiu chłopskich kandydatów, a jak podkreślano z dumą $\mathrm{w} \mathrm{KW}$, ,podobne osiągnięcia są również na innych powiatach naszego województwa",49.

W związku z trwająca żałobą w regionie aktywizowała się młodzież — największe inicjatywy upamiętniające osobę Józefa Stalina podjęto w dużych skupiskach młodzieżowych. Dla przykładu masówka na UMK odbyła się w obecności tysiąca studentów, co więcej, na tejże uczelni „nie stwierdzono dotychczas żadnych wystąpień reakcyjnej części młodzieży”.50. Ze względu na fakt, że na UMK znalazło zatrudnienie wielu profesorów b. Uniwersytetu Stefana Batorego w Wilnie, warto w tym miejscu zasygnalizować, iż społeczność ta prawdopodobnie w owym gorącym okresie zachowała neutralność w oficjalnie prezentowanych postawach i komentarzach. Można to wnioskować z dokumentacji Sekcji VI Wydziału V WUBP w Bydgoszczy, odpowiadającej za tzw. ochronę operacyjną UMK i prowadzącą sprawę agenturalnego rozpracowywania „Rdza” (profesura tzw. wileńska, której komuniści przypisywali „reakcyjne nastawienie do władzy ludowej”) ${ }^{51}$. Sprawę tę bowiem u progu 1954 r. przemianowano $\mathrm{z}$ agenturalnej na ewidencyjną, właśnie ze względu na stwierdzony „brak danych o zorganizowanej wrogiej działalności ${ }^{52}$ ",

Natomiast młodzi robotnicy z bydgoskiego Kombinatu Ceramicznego zainicjowali działalność brygady produkcyjnej, gdyż w zakładzie tym od dłuższego czasu nie udawało się wykonać założonego przez dyrekcję planu produkcji. Dzięki inicjatywie młodzieży, rzecz jasna przy współpracy aktywu robotniczego, plan ów zaczęto w końcu w pełni wyrabiać ${ }^{53}$. Na masówkach w Żninie, Toruniu i Aleksandrowie młodzi podejmowali spontanicznie decyzje o „trzymaniu warty przed portretami Stalina” usytuowanymi w miejscach publicznych. Młodzi z Ciechocinka zaciągnęli wartę przy popiersiu stojącym w świetlicy dworcowej ${ }^{54}$.

\section{„Wyczuwa się głęboki smutek i przygnębienie”. Stalin „wyciągnął nogi”. Nastroje, komentarze i opinie społeczne: oficjalne i rzeczywiste}

W okresie celebrowania żałoby partia komunistyczna zdołała odnotować wiele „negatywnych zjawisk". Jakkolwiek wraz z odbywanymi w skali całego województwa masówkami wzrastała liczba zobowiązań (na terenie Inowrocławia podjęło je sześć zakładów), to jednak w wielu fabrykach nie podjęto ich w ogóle (np. w Bydgoskiej Fabryce Mebli). Jak alarmowano, postawa załogi BFM wyniknęła z ,braku nastawienia przez dzielnicową instancję partyjną”. W regionie stwierdzono również (nieliczne) przypadki niewysłania przez załogi listu kondolencyjnego do przedstawicieli ZSRS w Polsce (np. w PZBM). Odnotowano także pewne rozprzężenie dyscypliny pracy wśród służb zabezpieczających ład i porządek w zakładach i fabrykach (,słabe ustawienie się po tej linii naszych pop" $)^{55}$. Dla przykładu we wspominanym już PZBM strażnicy SP pełniący dyżur wpuścili na teren zakładu bez legitymowania i stosownych przepustek grupkę przybyłych, jak się później okazało, dygnitarzy instancji par-

\footnotetext{
${ }^{49}$ Ibidem, Meldunek nr 59/53, 8 III 1953 r., k. 140.

${ }^{50}$ Ibidem, Meldunek nr 56/53, 7 III 1953 r., k. 149.

${ }^{51}$ IPN By 030/82, Raport z przeprowadzonej kontroli w Sekcji VI Wydziału V WUBP w Bydgoszczy, 22 I 1954 r., k.16. Zob. także: ibidem, Analiza materiałów po linii Sekcji VI Wydziału III PUBP w Toruniu, 21 VI 1956 r., k. 32.

${ }_{52}$ Ibidem, Raport z przeprowadzonej kontroli w Sekcji VI, k. 16.

${ }^{53}$ APB 1935/1586, Meldunek nr 56/53, 7 III 1953 r., k. 149.

${ }^{54}$ Ibidem.

${ }^{55}$ Ibidem, k. 148.
} 
tyjnej. W bydgoskim węźle kolejowym PKP aktyw tamtejszego Komitetu Partyjnego opuszczał teren zakładu, udając się do domu w godzinach pracy, zamiast monitorować społeczne nastroje i rozwijającą się sytuację. Skala tych zaniedbań w całym województwie musiała być niepokojąca, skoro dla zlikwidowania owych „niedociągnięć” nie tylko zwrócono uwagę komitetom miejskim, ale przede wszystkim nakazano organom wojewódzkim MO przeprowadzenie kontroli „po linii czujności straży przemysłowej” ${ }^{, 56}$.

Wspomnianych wyżej wypadków nie traktowano raczej jako celowego działania „wroga", a jedynie swego rodzaju zaniedbania, choć niedopuszczalne, organizacji partyjnych i administracji zakładów. W pierwszych chwilach po śmierci Stalina organizacja partyjna starała się w meldunkach do centrali raczej nie egzemplifikować komentarzy czy nastrojów negatywnych, wskazujących na pejoratywny stosunek do zmarłego. Dopiero z upływem czasu zaczęto informować Warszawę również o takich postawach mieszkańców województwa bydgoskiego. Tak jakby w odruchu obronnym w okresie pierwszego szoku po śmierci Stalina partyjni decydenci dawali wyraźny sygnał przełożonym w stolicy, że panują nad sytuacją.

Tak więc w meldunkach do Warszawy z 6 marca wskazywano w pierwszej kolejności na powagę sytuacji, jaka zapanowała w regionie. Używano określeń: „wyczuwa się głęboki smutek, panuje poważny nastrój i przygnębienie" ${ }^{, 57}$. Opisywano przy tym przypadki rozpaczy i łez w oczekiwaniu na wybuch kolejnej wojny. Tylko w jednym meldunku opisano dwa przykłady — jak się wydaje - autentycznej rozpaczy i strachu ${ }^{58}$. Pierwszy dotyczył aktywistki Ligi Kobiet publicznie rozpaczającej na ulicy (,„teraz może być wojna, bo dotychczas autorytet tow. Stalina wpływał na utrzymanie pokoju”); drugi — przewodniczącego jednej ze spółdzielni, który przybywszy we wczesnych godzinach rannych do PWRN we Włocławku, płakał w siedzibie rady, gdyż ,jak tow. Stalin żył, to był pokój, a teraz należy się raczej liczyć z wojną"59. Na podstawie partyjnych analiz można ustalić, iż znakomita część komentarzy i opinii społecznych miała pozytywny kontekst i nacechowana była „ogromnym przejęciem śmiercią tow. Stalina” oraz zapowiedziami nieszczędzenia sił dla realizacji wytycznych Stalina i partii ${ }^{60}$. Analiza nastrojów społecznych w regionie po śmierci genseka przekazywana oficjalnymi, partyjnymi kanałami dowodziła, że wiele osób, podobnie jak w Związku Sowieckim, opanowywała rozpacz i lęk. Płakano i tak jak w Sowietach wielu nie wyobrażało sobie przyszłości bez generalissimusa ${ }^{61}$. Na odbywających się dziesiątkach zebrań i masówek odnotowywano stosunkowo liczne komentarze członków partii i bezpartyjnych, przepełnionych „,bezgranicznym żalem” po śmierci Stalina. Warto w tym miejscu przywołać komentarz prof. Andrzeja Paczkowskiego, określający nastroje części społeczeństwa na wieść o śmierci Stalina; trafnie on bowiem oddaje atmosferę panującą również w woj. bydgoskim: „szok wywołany wiadomością o śmierci dyktatora był proporcjonalny do zasięgu władzy, którą dysponował"62. Członkini partii z gromady Kamień w powiecie sępoleńskim oświadczyła na zebraniu, iż „śmierć towarzysza Stalina przejęła ją do głębi, tak jak by jej zmarł ktoś z najbliższej rodziny" "63. Brygadzista z Zarządu Budowlanego nr $1 \mathrm{w}$ Bydgoszczy skonstatował, iż choć jest bezpartyjny, chce swoją pracą wykazać, że idea Stalina żyje, i w tym celu

\footnotetext{
${ }^{56}$ APB 1935/1586, Meldunek nr 56/53, 7 III 1953 r., k. 150.

57 Ibidem, Meldunek nr 54/53, 6 III 1953 r., k. 152.

${ }^{58}$ Ibidem.

${ }^{59}$ Ibidem.

${ }^{60}$ Ibidem, Meldunek nr 56/53, 7 III 1953 r., k. 148.

${ }^{61} \mathrm{Na}$ temat reakcji w ZSRS po śmierci Stalina zob. A. Ballock, Hitler i Stalin. Żywoty równoległe, cz. 2, Warszawa 1997, s. 434.

${ }^{62}$ A. Paczkowski, Pół wieku dziejów Polski, Warszawa 2005, s. 194.

${ }^{63}$ APB 1935/1586, Meldunek nr 58/53, 7 III 1953 r., k. 143.
} 
podejmie wraz z całą brygadą zobowiązanie do skrócenia czasu pracy „,na murach” o siedem dni roboczych ${ }^{64}$. Podobnych wypowiedzi odnotowywano w regionie ,,cały szereg"65.

Zdarzało się, że w nastroju histerycznej żałoby, multiplikowanej partyjną, wszechobecną propagandą i kultem zmarłego, wkrótce w regionie zaczęło dochodzić także do aktów społecznego samosądu i „demaskowania wrogów”. Oto na otwartym zebraniu partyjnym w Chodorążku w pow. lipnowskim chłopi „zdemaskowali” „zausznika kułackiego, malkontenta i zdecydowanego wroga, który siał ferment i panikę w gromadzie”. Następnie podjęli uchwałę o wykluczeniu go z partii, po czym wyrzucili z zebrania, „napiętnując mocno jego wrogie wystąpienie, co bardzo dobrze odbiło się wśród chłopów w gromadzie”. Jak argumentowano w dalekopisie do Komitetu Centralnego, ów człowiek ośmielił się głośno wypowiadać wiele ,plugawych kułackich oszczerstw, w tym ,głosić teorię, że jak tow. Stalin zmarł, to wojna jest nieunikniona, gdyż jak zmarł Piłsudski, to też była wojna"66.

W związku ze śmiercią Stalina organy bezpieczeństwa odnotowały przypadek wykorzystywania tej kwestii w porachunkach międzysąsiedzkich. Oto mieszkanka Świecka w powiecie wąbrzeskim, gospodyni domowa, złożyła doniesienie do powiatowych organów bezpieczeństwa na dwóch sąsiadów, którzy mieli ubliżać jej rodzinie i „wrogo wypowiadać się o Stalinie”. Jak ustalił referent UB, oddelegowany do sprawdzenia tego donosu, „wroga propaganda" antystalinowska nie miała miejsca, było to bowiem zwykłe nieporozumienie sąsiedzkie, jak się wydaje — po prostu próba ukarania złośliwych sąsiadów ${ }^{67}$.

Od 7 marca zaczęto w meldunkach do Warszawy podnosić kwestię aktywizacji elementu „wrogiego”, czyli informować o artykułowaniu przez część mieszkańców regionu różnorodnych form oporu będących de facto sprzeciwem wobec nachalnego kultu zmarłego i prostalinowskiej propagandy. Jakkolwiek 9 marca konstatowano, iż w regionie nie odnotowuje się ,jawnych wystąpień wroga", stanowiących dla władz największe zagrożenie, a jedynie można spotkać się „tu i ówdzie” z „wrogą plotką" szkalującą ZSRS i Stalina, to jednak liczba informacji i ich ciężar gatunkowy pozwalają wnioskować, że skala negatywnych komentarzy i opinii związanych ze śmiercią Stalina nie była mała. Odnotowywano również fakty niszczenia żałobnych dekoracji i portretów Stalina. Zgodnie z komunistyczną optyką ładu i bezpieczeństwa wszystkie tego typu zachowania, także wyrażanie zadowolenia ze śmierci genseka, toast na cześć zgonu czy też niewybredne komentarze ,,przeciwko Związku Radzieckiemu i tow. Stalinowi”, traktowano jak przestępstwo i we wszystkich tych wypadkach powiadomiono organy bezpieczeństwa, które wszczynały i prowadziły śledztwo ${ }^{68}$. Jak wynika ze sprawozdania szefa WUBP w Bydgoszczy za marzec 1953 r., na terenie województwa bydgoskiego stwierdzono wiele przypadków antyreżimowych komentarzy (tzw. szerzenie wrogiej propagandy), których źródłem w większości były zagraniczne radiostacje. Za odsłuchiwanie audycji zachodnich zatrzymano $\mathrm{w}$ regionie cztery osoby, a przesłuchano jedenaście, za propagowanie wrogich władzy komentarzy zatrzymano piętnaście osób, a przesłuchano czternaście. Za innego rodzaju ,wrogą działalność” zatrzymano dwie osoby i dodatkowo przesłuchano profilaktycznie kolejne dwie ${ }^{69}$.

\footnotetext{
${ }^{64}$ Ibidem, k. 144.

${ }^{65}$ Ibidem.

${ }^{66}$ Ibidem, Meldunek nr 59/53, 7 III 1953 r., k. 142.

${ }^{67}$ IPN By 030/48, Sprawozdanie z rozpatrzenia i odwołań skarg i zażaleń ludności w miesiącu maju 1953 r., k. 28; Sprawozdanie ze skarg i zażaleń ludności w miesiącu maju w PUBP w Wąbrzeźnie, 2 VI 1953 r., k. 258.

${ }^{68}$ APB 1935/1586, Meldunek nr 60/53, 9 III 1953 r., k. 134.

${ }^{69}$ IPN BU 1265/36/J, Sprawozdanie Szefa WUBP w Bydgoszcz za marzec 1953 r., k. 24.
} 
Analiza informacji zebranych przez instancje wojewódzkie PZPZR w zakładach pracy regionu dowodziła, iż od 7 marca zaczęto odnotowywać „,wrogie wypowiedzi pracowników”, co miało świadczyć, jakoby „wróg dotarł również i tam”. Jedną z formą biernego oporu na terenach zakładów pracy i instytucji były akty niszczenia żałobnych ozdób i haseł. W grudziądzkiej „Unii” zniekształcono hasło ,pokojowe”. Podobna rzecz się zdarzyła w stołówce siedziby związków zawodowych kolejarzy w Bydgoszczy, gdzie „,w podły sposób” postąpiono z hasłem „,dotyczącym osoby Stalina "70. Funkcjonariusze aparatu bezpieczeństwa raportowali w tym okresie, że ,ukryta robota wroga" polegała głównie na niewykonywaniu planów produkcyjnych, powodowaniu awarii i „,chęci dokonania aktów dywersji”, ${ }^{\text {, }}$.

W związku z narastaniem komentarzy wśród aktywu zaczęto podnosić kwestię ujawniającego się braku partyjnej czujności i zdecydowanego działania wobec „dalszej działalności wroga”. Podkreślano również „niedostateczną odporność, nawet niektórych członków Partii, którzy w nie dość zdecydowany sposób demaskują wystąpienia braku wiary w siłę Partii i Obozu Pokoju" 72 . W kilku powiatach województwa bydgoskiego (m.in. sępoleńskim i toruńskim), a także w samej Bydgoszczy pojawiły się znamienne komentarze nawiązujące do możliwości wybuchu kolejnej wojny, co również uznawano za działanie sił wrogich socjalistycznemu państwu: „Po śmierci Stalina wojna jest nieunikniona”, „wróg podszeptuje, że Stalin to pokój - nie ma Stalina, to chyba wojna"73.

Podczas dekoracji gmachu komitetu gminnego w Więcborku dziewczęta - podopieczne sióstr zakonnych - „wyśmiewały się szyderczo, wskazując ironicznie na flagi i dekoracje budynku KG, ${ }^{, 74}$. W ośrodku zdrowia w Koronowie pod Bydgoszczą sekretarz ośrodka podczas wysłuchiwania przez pacjentów komunikatu o śmierci Stalina zamknęła drzwi pokoju, gdzie znajdował się odbiornik radiowy, i pomimo uwag zebranych nie wyraziła zgody na odsłuchanie audycji do końca ${ }^{75}$.

Analiza poufnej dokumentacji partyjnej pozwala stwierdzić, że w całym regionie w okresie żałoby po zbrodniarzu odnotowano przypadki lekceważenia i kontestowania publicznie jego zgonu. Znamienna była tutaj postawa rektora UMK prof. Antoniego Basińskiego, który pojawił się na uroczystościach żałobnych dopiero na samo ich zakończenie, po czym po pięciominutowej ciszy zarządził ,,powrót do pracy”, ${ }^{~}$. Profesor Halina Turska, aktywizując studentów na zajęciach do poszukiwania synonimu słowa „śmierć”, przyczyniła się, zdaniem jednego z nich, do wielu niestosownych komentarzy (,wyciągnął nogi”, „wykopyrtnął się") ${ }^{77}$. Maszynistka z Gminnej Spółdzielni w Osieku (powiat rypiński) oświadczyła, iż „na tę intencję, że zmarł tow. Stalin, powinni dać 10 dni wolnego",78; aptekarz z Osięcin w pow. aleksandrowskim stwierdził, iż flagi są wywieszane „,chyba z radości, że umarł Stalin”, a pewien „Andersowiec” podczas rozmowy o śmierci Stalina „używał ohydnego i perfidnego wyrażenia"79. Oczywiście czasem mieszkańcy regionu artykułowali swój sprzeciw przeciwko kultywowaniu pamięci o Stalinie w dosadniejszej formie. Tak było w miejscowości Młynek (w gminie Koneck), gdzie podczas zebrania gromadzkiego poświęconego zmarłemu zostały

\footnotetext{
${ }^{70}$ APB 1935/1586, Meldunek nr 56/53, 7 marca 1953 r., k. 149.

1 IPN BU 1265/36/J, Sprawozdanie Szefa WUBP w Bydgoszcz za marzec 1953 r., k. 24.

2 APB 1935/1586, Meldunek nr 57/53, 7 marca 1953 r., k. 146.

${ }^{73}$ Ibidem, k. 146.

${ }^{74}$ Ibidem.

75 Ibidem, k. 147.

${ }^{76}$ Zob. szerzej: R. Kozłowski, Październik'56. w regionie, k. 14.

77 Ibidem.

${ }^{78}$ APB 1935/1586, Meldunek nr 58/53, 7 III 1953 r., k. 145.

${ }^{79}$ Ibidem.
} 
wybite szyby ${ }^{80}$, czy też w Grudziądzu, gdzie w nocy z 8 na 9 marca w siedzibie ZM ZMP „,nieznani sprawcy” dokonali włamania i zniszczyli mienie związku oraz kilka urządzeń ${ }^{81}$. W regionie zdarzały też wypadki strzelania do portretów zmarłego tyrana, i to także wśród kadry partyjnej ${ }^{82}$.

W dniu pogrzebu odnotowano antystalinowskie napisy na murach i budynkach mieszkalnych i zakładach pracy (np. w Mniszku k. Grudziądza, Pomorskiej Odlewni i Emalierni w Grudziądzu ${ }^{83}$ ). Z kolei po pogrzebie Stalina w ikonosferze regionu pojawiły się antyreżimowe druki. 10 marca w kilku miejscach Inowrocławia kolportowano ulotki o „treści związanej ze śmiercią Stalina”, wykonane na maszynie do pisania. Natychmiast je likwidowano na polecenie miejskiej instancji partyjnej, wysyłając w teren aktyw partyjny, któremu wydano polecenie wyzbierania ich aż do ostatniego egzemplarza ${ }^{84}$. Za ,,przejawy działalności wroga" uznano również rozpowszechnianie plotki, jakoby po śmierci Stalina nie będzie się już budować spółdzielni produkcyjnych (w gromadach powiatu aleksandrowskiego); komentarze na temat zmian w Rządzie ZSRS podjętych dopiero po śmierci genseka, a nie za jego żywota (miejscowości powiatu włocławskiego); czy też wyrażanie zdziwienia na wieść, iż zagranica uznaje Stalina za bohatera (powiat toruński) ${ }^{85}$. Jak alarmowano, w okresie poprzedzającym pogrzeb i w jego dniu działalność „wroga” ujawniała się również w „większym spożywaniu napojów alkoholowych przez zbankrutowanych kapitalistów, byłych właścicieli większych zakładów rzemieślniczych, kupców i kułaków" ". Co więcej — jak dowodzono — w zachowaniu przedstawicieli tych grup społecznych wyraźnie ,uwidocznił się wzrost aktywności w szkalowaniu imienia tow. Stalina oraz w szerzeniu wrogich plotek (m.in. ,partia dała polecenie modlenia się za tow. Stalina") ${ }^{87}$.

Ujawniająca się w dniach żałoby „wroga działalność kleru” była w owym czasie również dokładnie monitorowana. Jej rozmiary nie były znaczne i w zasadzie każdorazowo „dokumentowane” i ,wykrywane”. Zdaniem partyjnych sprawozdawców komentarze duchownych katolickich dotyczyły najczęściej „plotek związanych ze śmiercią tow. Stalina”, podkreślić szczególnie negatywny stosunek władz regionu do postaw toruńskich jezuitów, którzy starali się jakoby wszelkimi sposobami odwrócić uwagę młodzieży od uroczystości pogrzebowych, a do tego interpretowali zgon genseka na niwie teologiczno-filozoficznej. Świadczyły o tym wypowiedzi studentów Instytutu Wiedzy Religii, którzy dyskutowali kwestię śmierci i życia pozagrobowego właśnie poprzez optykę wiary katolickiej ${ }^{89}$. Spectrum „wrogiego działania” księży zdawało się nie wykraczać poza ramy kapłańskiej posługi i dekalogu, jednak dla rządzących wrogi był nawet fakt podjęcia na lekcji religii modlitwy za duszę tow. Stalina. Miało to miejsce np. w Więcborku (w powiecie sępoleńskim), gdzie na oświadczenie dzieci, iż zmarły był niewierzący, kleryk odparł, że to nie ma znaczenia ${ }^{90}$. W szkole podstawowej w Pluskowęsach (w powiecie wąbrzeskim) po lekcji religii, na której ksiądz nawiązał do śmierci Stalina w kontekście sakramentów świętych, dzieci stwierdziły,

\footnotetext{
${ }^{80}$ Ibidem.

${ }^{81}$ Ibidem, k. 23.; APB 1935/1586, Meldunek nr 62/53, 9 III 1953 r., k. 131.

82 R. Kozłowski, Październik '56 r. w regionie, s. 15; APB 1935, Protokół posiedzenia egzekutywy KW PZPR w Bydgoszczy, 21 VI $1957 \mathrm{r}$.

${ }^{83}$ APB 1935/1586, Meldunek nr 62/53, 9 III 1953 r., k. 133.

${ }^{84}$ Ibidem, Meldunek nr 63/53, 10 III 1953 r., k. 130.

${ }^{85}$ Ibidem, Meldunek nr 59/53, 7 III 1953 r., k. 142.

${ }^{86}$ Ibidem, Meldunek nr 62/53, 9 III 1953 r., k. 132.

${ }^{87}$ Ibidem.

${ }^{88}$ APB 1935/1586, Meldunek nr 59/53, 7 III 1953 r., k. 142.

${ }^{89}$ R. Kozłowski, Październik ' 56 w regionie, s. 15.

${ }^{90}$ APB 1935/1586, Meldunek nr 59/53, 7 III 1953 r., k. 142.
} 
że należałoby zdjąć jego portret z gazetki ściennej. Na szczęście żaden z uczniów nie odważył się na taki krok. Zważywszy, że wobec dzieci z tej samej szkoły, które przerobiły satyryczną piosenkę z okresu okupacji niemieckiej o Hitlerze na piosenkę o Stalinie, wszczęto dochodzenie w WUBP, uznać to należy za wyraz dużego rozsądku młodych ludzi. Co istotne i co podkreślali w swym meldunku funkcjonariusze partyjni, w szkole tej nie odczytano dzieciom nawet komunikatu o śmierci Stalina ${ }^{91}$.

Akty antysowieckie, kanalizujące niechęć i nienawiść do okupanta, który zniewolił kraj i naród, trwały w regionie przez cały rok 1953. Co oczywiste, przybierały rozmaite formy, miały też różny ciężar gatunkowy: od nieprzychylnych komentarzy po akty sabotażu (w grudniu 1953 r. w Brodnicy zostały przecięte druty linii telefonicznej eksploatowanej przez jednostki Armii Radzieckiej) ${ }^{92}$. Śmierć Stalina bez wątpienia wyzwoliła w wielu mieszkańcach regionu bydgoskiego odwagę do artykułowania śmielszych niż dotąd komentarzy dotyczących nie tylko osoby zbrodniarza, ale również Związku Sowieckiego oraz rządzących z jego nadania komunistycznych władz PRL. Przykładem może być sprawa bydgoskiego Okręgu Zarządu Kin. Na jego terenie w latach 1953-1955 ubowcy udokumentowali, przy pomocy zaufanego informatora ps. Róża, proceder „ośmieszania przywódców ZSRS i PRL” oraz „,przedstawianie w złym świetle posunięć rządów tych Państw”" ${ }^{\text {"93 }}$. Na szczęście oskarżona (dopiero po trzech latach, w 1956 r.!) Pelagia Świdurska podczas przesłuchania nie tylko nie przyznała się do winy, ale także podziękowała organom BP za „właściwą w treści i budującą rozmowę”. Przyznała również, że wysłuchiwała audycji RWE oraz oświadczyła, iż „dopiero teraz jej się otworzyły oczy, jak ma w swym życiu postępować" ${ }^{94}$.

U progu 1956 r. w środowisku toruńskiej adwokatury odnotowano nadal trwającą i podtrzymywaną ,tendencję rozmawiania ze Związkiem Radzieckim z pozycji siły”, która zdaniem bezpieki wynikała ze słuchania audycji RWE ${ }^{95}$.

\section{„Zadokumentować swoje przywiązanie do tow. Stalina i narodów Związku Radzieckiego". Czlonkowie aparatu partyjnego i administracyjnego wobec wydarzeń}

6 III 1953 r., zgodnie z wytycznymi KC PZPR, w związku ze śmiercią Stalina we wszystkich powiatowych i miejskich komitetach oraz w KW PZPR w Bydgoszczy odbyły się posiedzenia egzekutyw poświęcone pamięci Stalina. Jako że nie zachowały się materiały z posiedzenia tej wojewódzkiej egzekutywy, warto szerzej przytoczyć fragmenty zachowanych meldunków wysyłanych z terenu do Komitetu Centralnego, w których zawarta została wykładnia najważniejszych działań podjętych po zgonie Stalina w instancji wojewódzkiej ${ }^{96}$. Członkowie egzekutywy wojewódzkiej podkreślili przede wszystkim

\footnotetext{
${ }^{91}$ Ibidem, Meldunek nr 67/53, 17 III 1953 r., k. 120.

92 IPN By 030/24, Telefonogram do Gabinetu Ministra BP w Warszawie, Bydgoszcz 12 XII 1953 r., k. 6 .

${ }_{93}$ IPN By 030/82, Informacja Sekcji VI, 17 I 1956 r., k. 26.

${ }^{94}$ Ibidem.

${ }^{95}$ Ibidem, k. 27.

96 Teczka posiedzeń egzekutywy KW PZPR w Bydgoszczy za marzec 1953 r. zawiera szczątkowe materiały, dotyczące tylko zamknięcia roku obrachunkowego i dochodów w spółdzielniach produkcyjnych regionu oraz przebiegu w nich walnych zebrań. Temat śmierci Stalina podczas kolejnych, kwietniowych posiedzeń egzekutywy KW PZPR w Bydgoszczy powrócił tylko raz, w kontekście kwestii stanu przygotowania regionu do obchodów święta 1 maja. Na postawie: APB 1935/402, Ocena zamknięć roku obrachunkowego i podziału dochodów w spółdzielniach produkcyjnych województwa bydgoskiego, Bydgoszcz, 11 III 1953 r., k. 88-96; APB 1935/402, Zalecenia Egzekutywy KW PZPR w Bydgoszczy
} 
„konieczność nasilenia pracy masowo-politycznej oraz postulowali „ustawienie całej organizacji wojewódzkiej do czynnej walki z przejawami wrogich wystąpień, próbujących osłabić autorytet towarzysza Stalina i siać panikę w niewiarę i jedność partii”. Zwrócono również szczególną uwagę na uaktywnienie propagandy partyjnej na wszystkich jej szczeblach. Jeszcze tego samego dnia, w nocy, dyspozycje egzekutywy zostały rozesłane do wszystkich KP i KM ${ }^{97}$. Równolegle prowadzono akcje wysyłania telegramów i listów kondolencyjnych na ręce A. Sobolewa w celu — jak to określono — „zadokumentowania swojego przywiązania do tow. Stalina oraz narodów Związku Radzieckiego"98. W kolejnych dniach instancje partyjne całego województwa organizowały uroczyste posiedzenia, których głównym punktem były wystąpienia poświęcone pamięci zmarłego przywódcy. 7 marca we Włocławku podczas posiedzeniu plenarnego miejskiej instancji partyjnej I sekretarz Adam Górecki wygłosił referat poświęcony pamięci generalissimusa, „wielkiego Wodza i Nauczyciela [...] Wielkiego Kontynuatora nieśmiertelnego Lenina, Wodza wyzwolonych narodów, Geniusza Rewolucji, największej chluby i dumy naszej epoki — nieśmiertelnego Stalina”,99. Jak podkreślił w swoim wystąpieniu: „Żaden człowiek naszych czasów nie zdobył sobie takiego ogromnego, bezspornego wśród współczesnych — autorytetu, takiej powszechnej miłości setek milionów ludzi pracy, tak bezgranicznego zaufania narodów". Warto podkreślić, że stosowana wówczas nowomowa partyjna czy też język polityczny we wszystkich organizacjach partyjnych były w zasadzie zbliżone do retoryki wystąpienia Góreckiego, podobnie jak panująca na tych partyjnych zebraniach specyficzna atmosfera ${ }^{100}$.

Również 7 marca we wszystkich miastach województwa odbywały cię uroczyste sesje rad narodowych ${ }^{101}$. Swój akt oddania Stalinowi zaznaczyła mocnym akcentem wojewódzka instancja partyjna i władze administracyjne oraz czołowy aktyw partyjny, który wyjechał na Wybrzeże, aby „osobiście przekazać wyrazy bólu i współczucia z powodu zgonu tow. Stalina konsulowi ZSRS w Gdańsku" ${ }^{\text {"102. }}$. W skład delegacji wojewódzkiej weszli: I sekretarz KW PZPR, przewodniczący Prezydium WRN w Bydgoszczy, przewodniczący ORZZ, przewodniczący ZO ZSCH, przewodniczący ZW ZMP oraz - co podkreślono w meldunku towarzyszka Rzytelewska, czternastokrotna przodownica pracy i posłanka na Sejm PRL ${ }^{103}$. Warto podkreślić, że pogrzeb nie zamknął dyskusji partyjnej o roli generalissmusa. W wielu instancjach partyjnych wygłaszano odczyty i referaty poświęcone życiu i myśli „wielkiego Stalina", związane pośrednio z żałobą po zbrodniarzu, ale głównie z nową sytuacją polityczną, jaka powstała w bloku sowieckim. Dla przykładu 14 marca odbyła się odprawa nieetatowych pomocników Wojewódzkiej Komisji Kontroli Partyjnej, na którym jej wiceprzewodniczący odczytał referat $O$ życiu i działalności tow. Stalina, a także omówiono wytyczne wynikające z „nowej sytuacji po [jego] śmierci”. Zebrani raportowali o sytuacji społeczno-politycznej na podległym im terenie oraz podawali przykłady ,wrogich działań”. Jeden z nich, tow. Wałęsa

w związku z oceną przebiegu walnych zebrań w spółdzielniach produkcyjnych i podziału dochodów za rok 1952 w województwie bydgoskim, Bydgoszcz 17 III 1953 r., k. 75-79.

${ }^{97}$ APB 1935/1586, Meldunek nr 56/53, 7 III 1953 r., k. 148.

${ }_{98}$ Ibidem, Meldunek nr 58/53, 7 III 1953 r., k. 145.

99 R. Kozłowski, Wydarzenia roku 1956 w Polsce, w: Rok 1956 w Bydgoskiem. Materiaty z konferencji naukowej na temat „Bydgoski październik 1956 r.” pod red. Włodzimierza Jastrzębskiego, Bydgoszcz 1996, s. 10.

${ }^{100}$ Ibidem, k. 13-14.

101 Zob. „Gazeta Pomorska” 1953, nr 59, s. 6.

102 APB 1935/1586, Meldunek nr 58/53, 7 III 1953 r., k. 145.

${ }^{103}$ Ibidem. 
z Włocławka, poinformował, że „wiadomość o chorobie, a następnie śmierci tow. Stalina poruszyła społeczeństwo m. Włocławka [...], a jeśli idzie o działalność wroga, to miało miejsce podrzucenie papieru zapalonego w Fabryce Kujawianka" ${ }^{\text {"104 }}$.

Nieodzownym elementem żałoby po Stalinie był żywiołowy akces kandydatów do partii, który w regionie rozpoczął się od 5 III 1953 r., a jego apogeum przypadło na okres po pogrzebie. Intensywność i spontaniczność tego zjawiska przyrównać można chyba tylko do podejmowanych wówczas czynów społecznych i zobowiązań produkcyjnych. Początkowo napływ ten był umiarkowany. M.in. 7 marca w grudziądzkiej „Unii” do partii zgłosiło akces siedmiu przodowników pracy ${ }^{105}$; dwa dni później wnioski o przyjęcie do partii złożyło m.in. osiemnastu przodujących robotników z Bydgoszczy; dwudziestu dwóch z powiatu grudziądzkiego, jedenastu w Lipnie oraz ,szereg dalszych w innych powiatach” "106. Jak wynika z partyjnych statystyk, pomiędzy 2 a 9 marca wpłynęły 702 zgłoszenia do partii, w tym $670 \mathrm{w}$ okresie pomiędzy 6 a 9 marca. Jak podkreślano, „,największa ich ilość wpłynęła w dniu 9 marca”,107. Najliczniejszy akces zgłaszali robotnicy z zakładów produkcyjnych miast wydzielonych, wśród nich robotnicy-przodownicy pracy oraz kobiety i młodzież. Partię niepokoiła przede wszystkim ,niedostateczna liczba chłopów”, jaka przypadała na ogólną liczbę żywiołowo zgłaszających się nowych kandydatów ${ }^{108}$.

Dane dotyczące napływu kandydatów do partii pomiędzy 13 a 27 marca doskonale oddają skalę i masowość procederu, jaki nastąpił po iście cesarskich — trzeba przyznać — uroczystościach pogrzebowych celebrowanych w całym kraju. 13 marca w całym województwie akces do partii zgłosiły 1502 osoby $^{109}$; do 16 marca łącznie 1724 osoby $^{110}$; do 19 marca $2325^{111}$; do 27 marca - 2298 osób $^{112}$. Ogółem pomiędzy 6 a 31 marcem do PZPR zgłosiło się 2333 kandydatów ${ }^{113}$ (w tym odrzucono kandydatury 130 osób) ${ }^{114}$. Jeśli nawet nie wszyscy zgłaszający się do partii zostali przyjęci w jej poczet (brano bowiem pod uwagę stopień politycznego uświadomienia, postawę moralną oraz zaangażowanie $\mathrm{w}$ przodownictwo pracy) to jednak nowo przyjęci byli w swej masie ,świadomi obowiązków, jakie ciążą na kandydatach partii”, cechowała ich również „wysoka świadomość polityczna oraz przywiązanie do partii, władzy ludowej oraz Związku Radzieckiego"115. Fakt ten podkreślano wyraźnie w meldunkach sytuacyjnych wysyłanych z terenu województwa bydgoskiego do Centrali w Warszawie, uprzedzając ewentualny zarzut o brak kontroli i żywiołowość tego napływu.

Jak się zdaje, obawy takie nie były bezpodstawne. Otóż od pewnego momentu proces napływu kandydatów do partii poddany został w regionie ścisłej kontroli prowadzonej przez aparat etatowy komitetu wojewódzkiego. Sprawie tej poświęcono w KW PZPR nawet specjalną odprawę, zaopatrując wszystkie instancje powiatowe i miejskie w wytyczne dotyczące ścisłych procedur przyjmowania nowych członków. Dla zapobieżenia ,tendencji żywiołowości” kierownictwo KW zaczęło wkrótce przeprowadzać rozmowy z komitetami, które wyka-

\footnotetext{
104 APB 1935/904, Protokół z odprawy pełnomocników nieetatowych WKKP z dnia 14 III 1953 r., k. 56.

105 Ibidem, Meldunek nr 56/53, 7 III 1953 r., k. 149.

106 Ibidem, Meldunek nr 60/53, 9 III 1953 r., k. 134.

107 Ibidem, Meldunek nr 63/53, 10 III 1953 r., k. 130.

108 Ibidem.

109 Ibidem, Meldunek nr 66/53, 14 III 1953 r., k. 121.

110 Ibidem, Meldunek nr 70/53, 18 III 1953 r., k. 113.

111 Ibidem, Meldunek nr 72/53, 21 III 1953 r., k. 109.

112 Ibidem, Meldunek nr 75/53, 28 III 1953 r., k. 108.

113 Ibidem, Meldunek nr 77/53, 28 III 1953 r., k. 99.

114 Ibidem k. 100.

115 APB 1935/1586, Meldunek nr 70/53, 18 III 1953 r., k. 113-114.
} 
zały się brakiem odpowiedniej „czujności” w doborze kandydatów, lekceważąc ich postawę moralną, stopień uświadomienia politycznego czy też pochodzenie społeczne ${ }^{116}$. Sprawę tę postawiono również z całą mocą na forum WKKP w dniu 14 marca, co świadczy o wadze, jaką zaczęto przykładać do eliminowania z grona kandydatów, żywiołowo napływających po śmierci Stalina do partii, osób niepożądanych, uznawanych za „wrogie"

\section{„Naród Polski żegna Wielkiego Stalina”, czyli uroczystości pogrzebowe bez trumny...}

Ostatnim akordem żałoby po śmierci zbrodniarza był bez wątpienia dzień jego pogrzebu, celebrowany w całym kraju z największym rozmachem. Jak skonstatował prof. Jerzy Eisler: „Była to największa w dziejach Polski uroczystość żałobna poświęcona człowiekowi, który nie był Polakiem, a zarazem największa uroczystość, w której zebrani ludzie nie podążali za trumną" 118 . Wielką akcję informacyjno-propagandową przygotowała oczywiście partyjna „Gazeta Pomorska”, relacjonująca szeroko wydarzenia w ZSRS, PRL i w regionie. Wydanie „GP” poprzedzające pogrzeb, z 7-8 III 1953 r., opatrzono mottem: Stalin pozostanie zawsze $z$ nami. Dopiero pod tym hasłem pojawił się tytuł żałobnego artykułu poświęconego sowieckiemu przywódcy (Nieśmiertelne imię Stalina zawsze będzie żyć w sercach narodu polskiego $i$ całej postepowej ludzkości) ${ }^{119}$. Jak informował ten dziennik, ,,hołd pamięci wielkiego Stalina składali ludzie pracy Pomorza". Cytowano przy tym typowe w skali kraju i regionu komentarze, np. pracownika Bydgoskiej Fabryki Narzędzi deklarującego, „przez wzgląd na pamięć o Stalinie”, wykonywanie wszystkich jego wskazań. Pewien bydgoski drukarz opowiadał natomiast o „bezgranicznej boleści”, o tym, jak podczas druku żałobnego numeru „Gazety” musiał „mocno wytężyć wolę, bo tłukł się w sercu żal straszny” "120 10 marca na łamach „GP” ukazał się artykuł Ostatnia droga Józefa Stalina, opatrzony portretem zmarłego w trumnie wielkości jednej trzeciej strony. Jednocześnie w numerze tym zawarto wiele informacji na temat przebiegu uroczystości pogrzebowych w Moskwie, ostatniego pożegnania w skali ogólnopolskiej („Naród polski żegna Wielkiego Stalina”) oraz informacje z regionu (np. „w Toruniu młodzież zaciągnęła warty stalinowskie" $)^{121}$. Kampanię żałobną na podobną skalę prowadził również „Ilustrowany Kurier Polski”, będący organem sojuszniczego stronnictwa - SD $^{122}$.

Dużą rolę w propagowaniu kultu Stalina w okresie śmierci i żałoby odegrała bez wątpienia bydgoska rozgłośnia Polskiego Radia. Warto wspomnieć, że emitowany 5 marca „Dziennik Radiowy” relacjonował w atmosferze wzniosłości, jakoby tłumy bydgoszczan przystawały na ulicy przed głośnikiem, wysłuchując komunikatów o stanie zdrowia genseka (na twarzy „głęboka troska, w oczach smutek”) ${ }^{123}$, a kiedy z głośnika płynął głos informujący o tym, to wówczas ,usta milionów na całym świecie szepcą: Stalinie żyj, żyj nam! Żyj!”,"24.

\footnotetext{
116 Ibidem, Meldunek nr 72/53, 21 III 1953 r., k. 109.

117 APB 1935/904, Protokół z odprawy pełnomocników nieetatowych WKKP z dnia 14 III 1953 r., k. 57.

118 J. Eisler, Życie codzienne w Warszawie w okresie Planu Sześcioletniego, w: Polska 1944/45-1989. Życie codzienne 1945-1955. Studia i materiały, t. V, Warszawa 2001, k. 42.

119 „Gazeta Pomorska” 1953, nr 57, s. 1. W numerze tym także m.in. wiersze Jerzego Putramenta oraz fragment powieści Ilii Erenburga Wielkie uczucie.

120 Ibidem, s. 5.

${ }^{121}$ Ibidem, 1953, nr 59, s. 5, 6.

${ }^{122}$ Zob. R. Kozłowski, Październik '56 w regionie, s. 12 (zob. przyp. 7).

123 Cytaty na podstawie: M. Rzepa, Pierwsze lata powojenne, w: Polskie Radio na Pomorzu i Kujawach 1935-2005, red. W. Jastrzębski, M. Rzepa, Bydgoszcz 2005, s. 71.

${ }^{124}$ Ibidem.
} 
7 marca poświęcono Stalinowi całodzienny program, podczas którego nadano m.in. audycję literacką Przestało bić wielkie serce, Kantatę o Stalinie W. Broniewskiego i Poemat o Stalinie T. Kubiaka ${ }^{125}$ ).

Warto więc w tym miejscu zauważyć, że sposób, w jaki lokalne media traktowały sprawę choroby, śmierci i pogrzebu Stalina, a także jak w ogóle przedstawiano Polakom obraz ZSRS, pokazywał najlepiej, jak ,naginając i koloryzując rzeczywistość” w sposób „niepohamowany”, ,absurdalny”, propaganda komunistyczna kreowała istniejącą rzeczywistość pod wpływem bieżącej sytuacji politycznej ${ }^{126}$. Jak pisał J. Wojsław zajmujący się propagandą komunistyczną w okresie stalinizmu w Polsce, obraz teraźniejszości kreowany przez komunistyczną propagandę na użytek rządzących stanowił ,zbiór zdeterminowanych życiem w ustroju komunistycznym wirtualnych prawd"127. Co więcej, w marcu 1953 r. komuniści połączyli Wydział Propagandy Masowej i Szkolenia Partyjnego, w wyniku czego powstał Wydział Propagandy i Agitacji ${ }^{128}$, a wkrótce (w sierpniu 1953 r.) na mocy uchwały Sekretariatu KC utworzono przy komitetach wojewódzkich słynne WUML-e) ${ }^{129}$. Instytucje te zapewniały sprawne funkcjonowanie propagandy - drugiego, po terrorze, filaru komunistycznego reżimu.

Zdaniem władz partyjnych cała uroczystość pogrzebowa z 9 III 1953 r. odbyła się w skali regionu w „sposób właściwy”. Na odgłos bijących dzwonów, syren i radia zamarł wszelki ruch kołowy i pieszy, stanęły maszyny w halach produkcyjnych. Po pięciu minutach ciszy w zakładach pracy, urzędach i instytucjach powrócono do przerwanej pracy, lecz w wielu z nich zainicjowano warty produkcyjne, a w wyniku ,właściwego ustawienia organizacji partyjnych” odnotowano nawet większą wydajność pracy ${ }^{130}$. Tego dnia w całym regionie zorganizowano również po południu czterdzieści trzy żałobne zgromadzenia z udziałem 42 tys. osób (tym 13,5 tys. kobiet, 11,5 tys. młodzieży) oraz 237 delegacji przybyłych ze wsi. Zebrani nieśli przybrane kirem

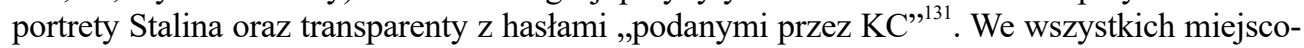
wościach, w których odbywały się owe masowe wiece żałobne, przyjmowano rezolucje oraz wysłuchiwano transmisji radiowej z uroczystości pogrzebowych w Moskwie. Jak podkreślali partyjni sprawozdawcy, szczególnym zainteresowaniem cieszyło się wystąpienia Malenkowa, zwłaszcza fragmenty nawołujące do zachowania pokoju na świecie. W kontekście wydarzeń w Korei miało ono przecież silny wydźwięk propagandowy. Transmisji tej zbiorowo wysłuchiwały załogi dziesiątków zakładów pracy, uczniowie w szkołach, pracownicy w urzędach. Spora część organizowanych wówczas zgromadzeń wysyłała listy i telegramy kondolencyjne do ambasadora ZSRS w Warszawie. Warto dodać, że wśród mieszkańców woj. bydgoskiego tego dnia dużą popularnością cieszyły się emblematy, znaczki, naszywki z podobizną Stalina, szczególnie przez mieszkańców wsi eksponowane na ubraniu wierzchnim. Jak sygnalizowały niektóre komitety partyjne, znaczków wyraźnie brakowało, co powodowało rozgoryczenie tłumów przybywających do partyjnych siedzib w celu ich otrzymania ${ }^{132}$.

\footnotetext{
${ }^{125}$ Ibidem, s. 72.

${ }^{126}$ M. Czyżniewski, Obraz społeczeństwa radzieckiego w prasie pomorskiej (1945-1953), „Zapiski Historyczne" 2001, t. LXVI, z. 1, s. 78.

127 Za: J. Wojsław, Obraz teraźniejszości w propagandzie komunistycznej Polski lat 1949-1954. Zarys problematyki, Gdańsk 2009, s. 127.

${ }^{128}$ W 1954 r. dołączono do niego Wydział Prasy; na temat kolejnych zmian w organach propagandowych w strukturach KC zob. M. Czyżniewski, Propaganda polityczna władzy ludowej w Polsce 19441956, Toruń 2006, s. 53.

${ }^{129}$ Ibidem, s. 56.

${ }^{130}$ APB 1935/1586, Meldunek nr 62/53, 9 III 1953 r., k. 131.

131 Ibidem, Meldunek nr 63/53, 10 III 1953 r., k. 128.

${ }^{132}$ Ibidem, Meldunek nr 62/53, 9 III 1953 r., k. 131.
} 
Podczas dziesiątków uroczystości organizowanych w skali całego regionu miały miejsce zarówno chwile określane przez partie jako „wzniosłe”, jak i próby „zakłócenia” ich przebiegu. W Toruniu na jednym z zebrań zgromadzeni aż dwukrotnie wstawali z miejsc za sprawą emocjonalnego wystąpienia sekretarza partyjnego. Zdaniem partyjnych dygnitarzy był to dobry przykład egzemplifikujący postawę „głębokiej powagi i skupienia” ludności województwa w dniu pogrzebu ${ }^{133}$. Tego dnia załogi wielu zakładów podejmowały dodatkowe zobowiązania produkcyjne, w Grudziądzkich Zakładach Mechanicznych już po czterech godzinach pracy wielu robotników wyrobiło 300 proc. normy, a „brygada Kosowskiego” w Zarządzie Budowlanym w Bydgoszczy wykonała 700 proc. normy, chociaż przeciętnie wykonywała 400 proc. ${ }^{134}$ Nie obyło się jednak i bez incydentów, uznawanych przez partię za groźne. Na przykład w Nieszawie podczas retransmisji uroczystości z Moskwy w trakcie przemówienia Mołotowa wyłączone zostały na dziesięć minut głośniki, co spowodowało wyjście około dwustu osób słuchających audycji. W sprawie tej milicja natychmiast wszczęła dochodzenie $^{135}$.

Ważnym momentem w trakcie trwającej w całym regionie żałobnej celebry był odgłos dzwonów kościelnych, jaki rozległ się około dziesiątej rano w 430 katolickich świątyniach (na 458 kościołów istniejących w całym województwie). Tego dnia prawie we wszystkich polskich świątyniach w ten sposób uczczono pamięć Stalina, przy niewielkim tylko oporze niektórych duchownych ${ }^{136}$. Ci spośród nich, którzy odmówili bicia w dzwony, powoływali się na zarządzenie obowiązujące w Kościele katolickim, iż robi się to tylko w przypadku pogrzebów katolików. W Bydgoszczy jeden z dziekanów — ks. Skonieczny — przed oficjalną godziną pogrzebu zebrał część duchownych i odmówił bicia w dzwony. Niektórzy duchowni $\mathrm{z}$ regionu, mimo iż obiecali w rozmowie $\mathrm{z}$ urzędnikami WRN, że polecą bić w dzwony, ostatecznie tego nie zrobili. Część jednak polecenie władz wykonała chętnie, argumentując, że „zdaje sobie sprawę z zasług zmarłego Wodza, który oswobodził naród polski spod jarzma hitleryzmu”; czy też dowodząc, że ,nawet papież odprawia modły za tak Wielkiego Człowieka, jakim jest Stalin" ${ }^{\prime 137}$. Dziekani i kurie biskupie w regionie nie wydały żadnych dyrektyw dla podległego sobie duchowieństwa w tej kwestii, poza jednym wyjątkiem — kurią włocławską, w której bp Korszyński polecił wykonać zarządzenie komunistycznych władz i bić w dzwony. Biskup ten osobiście telefonował do „opornych” księży z terenu ${ }^{138}$. Zdarzało się i tak, iż duchowny odmówił, jednak w dzwony i tak w jego kościele bito... A to za sprawą aktywistów partyjnych i ZMP, których na dzwonnicę wpuszczali, najczęściej potajemnie, pracownicy plebanii (sprzątaczka, organista, kościelny). Tak było np. w gromadzie Szczutowo w powiecie rypińskim, gdzie mimo sprzeciwu księdza kościelny pomógł aktywowi w dzwonieniu, argumentując, iż „Stalin dużo pomógł Polsce i jemu samemu i dlatego on dzwonić będzie, a ksiądz niech sobie robi, co chce"139.

Powszechna w swym wymiarze żałoba po śmierci Stalina przypominała dobrze wyreżyserowany spektakl teatralny, o którego scenariusz z wielką pieczołowitością zadbali osobiście członkowie KC PZPR. Zdaniem niektórych badaczy zabrakło w owym spektaklu ,zwykłych

\footnotetext{
133 Ibidem, k. 128.

${ }^{134}$ Ibidem, Meldunek nr 63/53, 9 III 1953 r., k. 129.

${ }^{135}$ Ibidem, k. 128.

136 Zobacz: R. Kozłowski, Październik '56 r. w regionie, s. 13. Zob. także: R. Kupiecki, Natchnienie milionów, s. 173-175.

${ }^{137}$ APB 1935/1586, Meldunek nr 62/53, 9 III 1953 r., k. 131.

138 Ibidem, k. 132.

139 Ibidem.
} 
ludzkich odruchów z powodu straty kogoś bliskiego. Jeżeli nawet tu i ówdzie pojawiał się płacz wśród żałobników, to były to raczej rzadkie przypadki"140.

28 marca na specjalnym VIII Plenum KC PZPR poświęconym pamięci Stalina wybijał się w dyskusji głos Władysława Kruczka, którego wystąpienie doskonale korelowało z żałobnym referatem występującego przed nim I sekretarza Komitetu Centralnego Bolesława Bieruta, perorującego o „nieśmiertelnych naukach towarzysza Stalina"141. Jednak w kwietniu podczas obrad Egzekutywy KW PZPR w Bydgoszczy ${ }^{142}$ temat Stalina powrócił tylko raz i tylko kontekstowo. W czasie omawiania stanu regionalnych przygotowań do obchodów 1 maja informowano, że choć przebiegają one zgodnie z planem, to jednak odnotowano wypadki „słabej kontroli części artystycznej, przeważnie w szkołach”. Dodatkowo w jednej z nich, w Bydgoszczy, po smutnym wierszu o śmierci tow. Stalina przygotowano „lekką piosenkę" ${ }^{143}$. Władze regionu, zdając sobie sprawę z wagi bezkonfliktowego przebiegu obchodów święta pracy w niespełna dwa miesiące po śmierci Stalina, postanowiły wysłać na podbydgoską wieś łącznie 134 ekipy zabezpieczające „polityczną stronę święta”. Na kilka dni przed uroczystościami instancja wojewódzka dopracowała również ,wszystkie organizacyjne szczegóły". Warto zaznaczyć, że tego roku instancja partyjna z Kruczkiem na czele kładła szczególny nacisk, na to aby na wszystkich szczeblach partyjnych „tegoroczny 1 maja był radośniejszy od wszystkich poprzednich" ${ }^{\text {"144 }}$.

\section{Zakończenie}

Mimo ogromnego wysiłku organizacyjnego KW PZPR włożonego w przygotowanie i monitorowanie przebiegu uroczystości żałobnych oraz zabiegów partyjnych propagandzistów, zmierzających do masowej konsolidacji społeczeństwa wokół ideologii PZPR, nie udało się wojewódzkim decydentom partyjnym wykorzystać potencjału tkwiącego w nastrojach ludności po 5 III 1953 r. Jakkolwiek uroczystości po śmierci Stalina — zarówno ich przebieg, jak i skala — stały się widomym znakiem hegemonii komunistycznej partii, to jednak nie zdołano ich przekuć na rzeczywiste polityczne aktywa. Sytuacja była na tyle niepokojącą, że zdaniem KW należało w całym regionie przeprowadzić natychmiastowe odprawy sekretarzy pop w KP i KM w celu wzmocnienia ,czujności w zakładach pracy, mobilizacji do produkcji, przodownictwa Partii i szerszego omówienia tekstów oficjalnych". Jak meldowano bowiem do Warszawy: „niektórzy sekretarze pop nie dość głęboko pojmowali polityczne zadanie obecnej sytuacji”. Pod koniec marca podsumowano: „Ogólnie należy ocenić, że KP i KM nie potrafiły zdyskontować należycie politycznych nastrojów, jakie wywołała śmierć Stalina, zwłaszcza na wsi, i nie widziały konieczności zrealizowania grudniowej uchwały KC na odcinku rozwoju i umacniania partii na terenach politycznie zaniedbanych, jak również świadczy o tym znaczna ilość pracowników umysłowych, w tym urzędników, których egzekutywy KP i KM zatwierdzają na kandydatów Partii" "145.

14 marca, podczas specjalnego posiedzenia bydgoskiej WKKP, stwierdzono na jej forum w sposób kategoryczny, że należy natychmiast (,,po śmierci Stalina”) wzmóc „,wykonanie pla-

\footnotetext{
${ }^{140}$ Cytat za: R. Kozłowski, Październik '56 r. w regionie, s. 17.

141 R. Kupiecki, Natchnienie milionów, s. 199, 200.

142 APB 1935/403, Protokoły z posiedzeń Egzekutyw KW PZPR w Bydgoszczy (kwiecień 1953 r.).

${ }^{143}$ Ibidem, Protokół nr 22/53 z posiedzenia Egzekutywy KW PZPR w Bydgoszczy odbytego w dniu 28 IV 1953 r., k. 80.

144 Ibidem.

145 Ibidem; APB 1935/1586, Meldunek nr 72/53, Bydgoszcz, 21 III 1953 r., k. 109.
} 
nów i czujność”. Zdaniem kierownictwa komisji niewykonanie produkcji planowej „powinno być sygnałem, że należy bliżej się zainteresować ludźmi tam pracującymi"146. Nakazano także „doszukiwać się wrogiej działalności” w awariach mających miejsce w zakładach, a wszystkie „wrogie wypowiedzi o Stalinie” — surowo karać. „Najważniejsze zagadnienie, z jakim teraz wszyscy powinni żyć, to akcja wiosenno-siewna, należy zwrócić uwagę, aby nie było żywiołowości w napływie do partii, aby nie przeniknął element wrogi” — podsumowywał dyskusję kierujący WKKP tow. Nowak ${ }^{147}$.

Była to już jasna i czytelna zapowiedź kolejnego ostrego kursu w polityce wewnętrznej PZPR, która nastąpiła po śmierci Stalina, szczególnie widoczna i odczuwalna już od miesięcy letnich na podbydgoskiej wsi. A jednak, jak pisał Dmitruk Wołkogonow, jeden z biografów Stalina: „wraz z aktem pogrzebu rozpoczynał się trudny i długi proces uwalniania się od jednej z najstraszliwszych tyranii w historii" ${ }^{\prime 148}$.

W biografii zbrodniarza opublikowanej pod koniec lat osiemdziesiątych jej autor M. Mikeln zawarł znamienną frazę: Kiedy umarł Stalin, płakały tłumy. Dzisiaj nikt z jego rodziny nie nosi nawet jego nazwiska"149.

Słowa kluczowe: Józef Stalin, zgon, śmierć, pogrzeb, żałoba, województwo bydgoskie, 1953 r., PZPR, wiece, masówki, propaganda

\section{Bibliografia}

Ballock A., Hitler i Stalin. Żywoty równoległe, cz. 2, Warszawa 1997.

Courtois S., Werth N.,.Panné J. L, Paczkowski A., Bartošek K., Margolin J. L., Czarna księga komunizmu. Zbrodnie, terror, prześladowania, Warszawa 1999.

Czyżniewski M., Propaganda polityczna władzy ludowej w Polsce 1944-1956, Torun 2006.

Kozłowski R., Październik '56 $w$ regionie kujawsko-pomorskim $w$ świetle niepublikowanych źródel PZPR, Włocławek 2004.

Kupiecki R., Natchnienie milionów. Kult Stalina 1944-1956, Warszawa 1993.

Machcewicz P., Polski rok 1956, Warszawa 1993.

Mawdsley E., Czas Stalina, Warszawa 2012.

Montefiore S. S., Stalin. Dwór czerwonego cara, Warszawa 2010.

Paczkowski A., Pól wieku dziejów Polski, Warszawa 2005.

Polska 1944/45-1989. Życie codzienne 1945-1955. Studia i materiaty, t. V, Warszawa 2001.

Polskie Radio na Pomorzu i Kujawach 1935-2005, red. W. Jastrzębski, M. Rzepa, Bydgoszcz 2005.

Rok 1956 w Bydgoskiem. Materiały z konferencji naukowej na temat „Bydgoski październik 1956 r.” pod red. Włodzimierza Jastrzębskiego, Bydgoszcz 1996.

Snyder T., Skrwawione ziemie. Europa między Hitlerem a Stalinem, Warszawa 2011.

Wołkogonow D., Stalin, t. II, Warszawa 1998.

Wojsław J., Obraz teraźniejszości w propagandzie komunistycznej Polski lat 1949-1954. Zarys problematyki, Gdańsk 2009.

Wójtowicz P., Obraz Związu Sowieckiego w ujęciu polskie emigracji politycznej w Wielkiej Brytanii, Warszawa 2008.

\footnotetext{
146 APB 1935/904, Protokół z odprawy pełnomocników nieetatowych WKKP z dnia 14 III 1953 r., k. 57.

${ }^{147}$ Ibidem.

${ }^{148}$ D. Wołkogonow, Stalin, t. II, Warszawa 1998, s. 372.

149 Za: M. Mikeln, Stalin, Warszawa 1990, s. 5.
} 


\section{Social Reactions to the Death of Joseph Stalin and the Propaganda Campaign Relating to Funerary Ceremonies in the Voivodeship of Bydgoszcz in March 1953}

The author attempted an analysis of the social situation prevailing in the voivodeship of Bydgoszcz in connection with the agony and death of Joseph Stalin in March 1953. A chronological-factual interpretation examines the propaganda undertakings of authorities cultivating the memory of the dictator, both at the time of his agony and after his death, as well in the course of the funerary ceremonies and mourning. The author also described official and actual reactions, commentaries and opinions of the local inhabitants, the press and propaganda campaign (decorations of public space, rallies, mass meetings, campaigns, and commitments). Other examined factors include assorted forms of social resistance, which were a de facto form of protest against the intrusive cult of the deceased and pro-Stalinist propaganda (e.g. the destruction of declarations and portraits of Stalin, as well as dismissive attitudes contesting the official mourning). Attention has been drawn to the fact that an indispensable element of the mourning was a spontaneous tide of candidates to the Polish United Workers' Party, a process not controlled to the very end by the communists (on 6-31 March a total of 2333 inhabitants of the voivodeship of Bydgoszcz wished to join the Communist Party, with 130 candidates rejected). Summing up, the author stressed that despite the enormous propaganda efforts of the Party-administrative authorities of the voivodeship of Bydgoszcz and the great number of candidates to the Party it was impossible to make full use of the political mood caused by Stalin's death in the so-called politically neglected terrains, and in particular in the villages of the Kujawy-Pomerania region. 